\title{
2D INTERPRETATION OF SUBSURFACE HOT SPRING GEOTHERMAL STRUCTURE IN NYELANDING VILLAGE THROUGH SCHLUMBERGER GEOELECTRICITY CONFIGURATION METHOD
}

\author{
Rahmat Nawi Siregar*1, Widodo Budi Kurniawan ${ }^{2}$ \\ 1,2 Physics Department, Universitas Bangka Belitung, Pangkal Pinang, Indonesia \\ *Correspondence address: rahmatnawisiregar@gmail.com \\ Accepted: January $10^{\text {th }}, 2018$. Approved: April 12 $2^{\text {nd }}, 2018$. Published: April $28^{\text {th }}, 2018$
}

\begin{abstract}
This research was done on the subsurface structure of Nyelanding village hot spring, Air Gegas district, South Bangka with coordinates $2^{\circ} 44^{\prime} 54.514$ " South Latitude and 106 ${ }^{\circ} 16^{\prime} 6.773^{\prime \prime}$ East Longitude using the Schlumberger geoelectricity configuration method. Measurements were made on three different tracks. The results of the Schlumberger configuration geoelectricity measurements for the three trajectories indicate the presence of granite rock distribution with resistivity values ranging from $455-1046 \Omega \mathrm{m}$.
\end{abstract}

C 2018 Physics Education, UIN Raden Intan, Lampung, Indonesia

Keywords: geothermal hot spring, Schlumberger geoelectricity configuration.

\section{INTRODUCTION}

The tectonic plates of Sumatra Island is indicated by the akrasia prism (Simelue Island, Nias Island, Telo Island, Engganau Island, Batu Island and Mentawai Island), the outer arc basin, the volcanic arc (row of volcanoes along the ridge) and the rear arc basin (Bangka Island, Belitung Island and Riau Islands) (Barber, Crow, \& De Smet, 2005). This tectonic order will be a means for the emergence of geothermal sources associated with young volcanoes. There are 84 geothermal manifestation points located on the island of Sumatra, and most of them are the result of geothermal thrust originating from volcano magmatic activity. However, some geothermal manifestations such as Pemali, Dendang, Permis and Nyelanding hot springs in Bangka Island are volcanoes that are thought to have nothing to do with volcanic activity (Ananda, Ahman, \& Riwanudin, 2013; Pitulima et al., 2016; Santoso, 2016; Setiawan, D \& Adhitya, 2013).
The presence of geothermal manifestations in Bangka Island that do not have volcanoes and very low levels of seismicity becomes a challenge for researchers. Research, publications, and literature explaining the phenomenon of non-volcanic geothermal in Indonesia in general and Bangka Island, in particular, are still very small in number.

This is what encourages the writers to do further research on "The Analysis of Subsurface Hot Spring Geothermal Structure in Nyelanding Village through Schlumberger Geoelectricity Configuration Method," which may provide additional literature on nonvolcanic geothermal studies in Indonesia.

\section{THEORETICAL FRAMEWORK}

Physiographically, Bangka Island is the largest island in Sunda Shift and is represented by hilly terrain with bedrock that limits the South Sumatra Basin in the east and the Sunda Basin in the north (Barber et al., 2005). Nyelanding village is located in the formation area of Tanjung 
Genting, where the geology of this area is controlled by the thrust of clay granite rock as shown in Figure 1. The weathered and clotted granite is filled by iron oxide and quartz. In this area also found the existence of sandstone which is the result of weathering of granite (Margono, Supandjono, \& E, 1995).

The formation of geothermal systems in several manifestations on
Bangka Island is thought to be associated with a large-dimensional plutonic body of rocks, i.e., batholiths, granites from the late Triassic to early Jurassic period. With the old age of rocks, it is estimated that the remaining heat from magma is very little (Purwoto, Rezky, \& Simarmata, R, S, 2015).

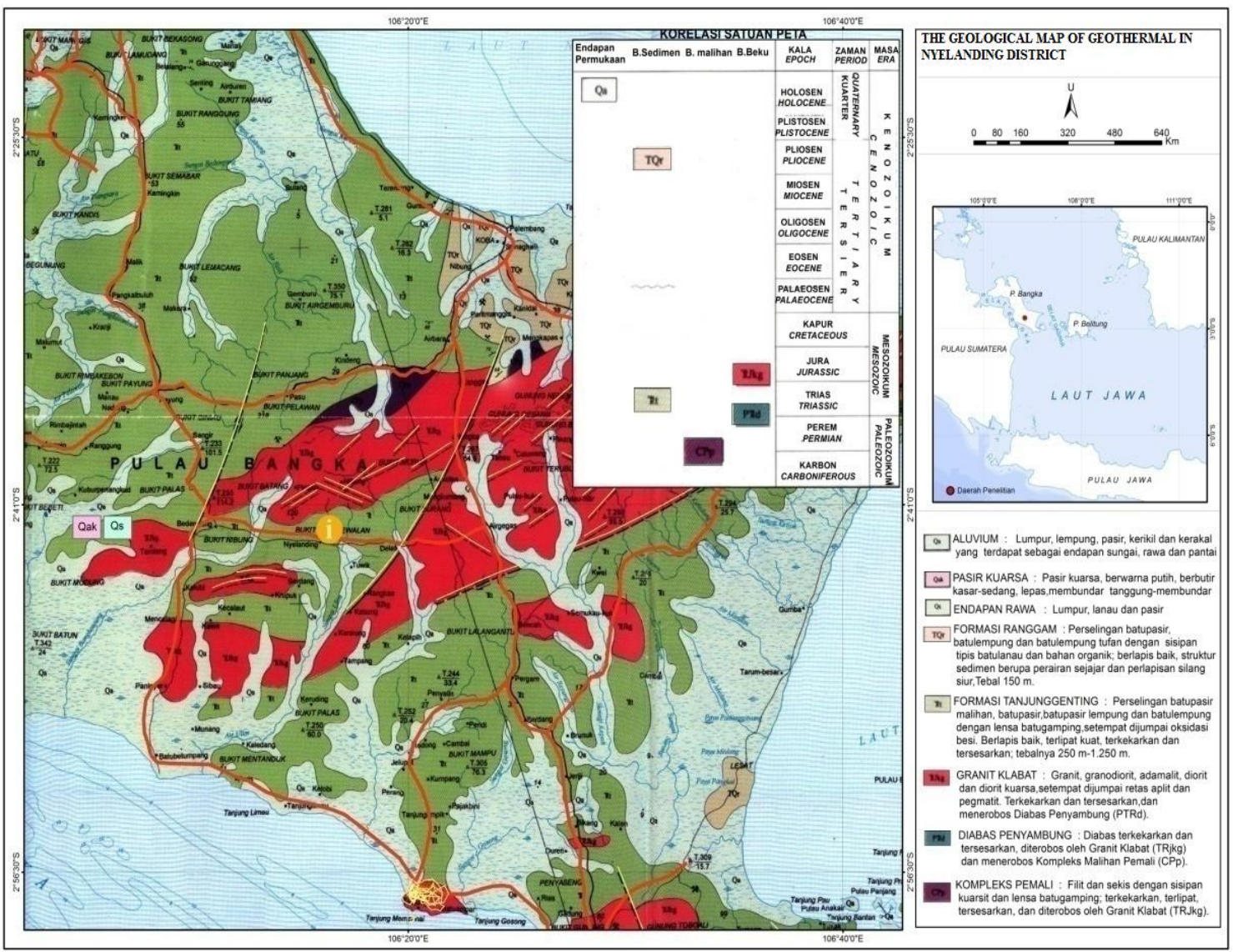

Figure 1. The Geological Map of Geothermal in Nyelanding Village

The distribution of plutonic rock as a carrier of radioactive elements follows the direction of the folds and trajectories of the coastline of Bangka Island which follows the direction of specific geological structures of the fold axis. Fracture and fault structures have many orientations. The north-south fault pattern is the youngest fracture phase (Muslim, Kristiyanto, \& Endyana, 2015; Permana, Handayani, \& Gaffar, 2010). The rising and normal fault has a relatively northwest-southeast direction, and a horizontal fault with a relatively northsouth direction cuts the older fault (Franto, 2015).

Geoelectricity method is an active geophysical method that utilizes the Voltage that arises because the electric current is injected into the soil. These Voltages provide information about the shape and electrical properties of non- 
homogeneous stratum (Siregar, R, Sinarta, I, Ervan, \& Sismanto, 2016). Geoelectricity methods can be used to identify subsurface structures in geothermal investigations. This can be demonstrated by the cross-section of rock type resistance associated with geothermal heat.

Measurement of a resistive type on an isotropic homogeneous medium can be performed on a cylindrical sample as can be seen in figure 2 .

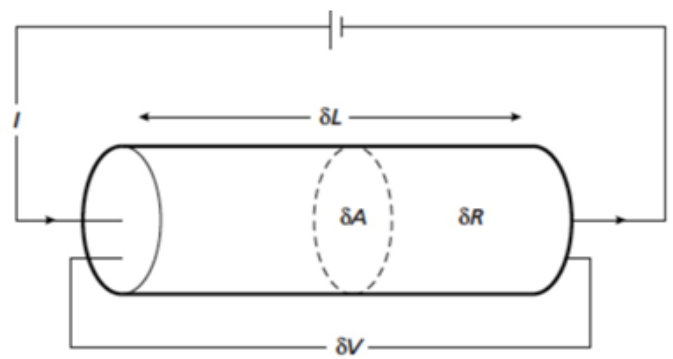

Figure 2. Electric current through a homogeneous cylinder

For a cylinder conductor that has a resistance value of $\delta R$, length $\delta L$, and width $\delta A$ then the resistivity $\varrho$ can be formulated as :

$$
\rho=\frac{\delta R \delta A}{\delta L}
$$

The unit of resistivity is ohm-meter (ohm $\mathrm{m}$ ), and the opposite of resistivity is the conductivity unit of $\mathrm{ohm}^{-1} \mathrm{~m}^{-1}$.

Geoelectricity measurements used in the field consisted of two electrons to carry the current $(\mathrm{C} 1$ and $\mathrm{C} 2)$ and two other electrodes ( $\mathrm{P} 1$ and $\mathrm{P} 2)$ to measure the current Voltage (Fig. 3). Setting the distance between different current and potential electrodes will give different depth information as well

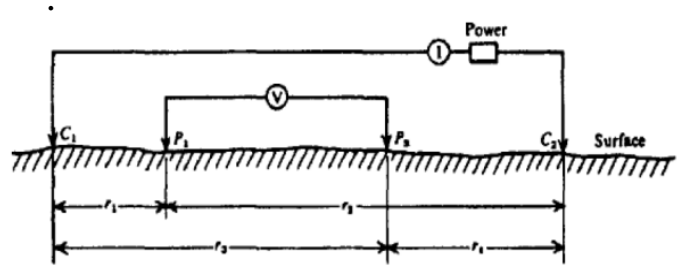

Figure 3. The configuration of the current and potential electrode
The potential in point $\mathrm{P} 1$ is

$$
V_{p 1}=\frac{\rho I}{2 \pi}\left(\frac{1}{R_{1}}-\frac{1}{R_{2}}\right)
$$

The potential in point $\mathrm{P} 2$ is :

$V_{p 2}=\frac{\rho I}{2 \pi}\left(\frac{1}{R_{3}}-\frac{1}{R_{4}}\right)$

Then the Voltage between the two points is,

$$
\Delta V=\frac{\rho I}{2 \pi}\left\{\left(\frac{1}{R_{1}}-\frac{1}{R_{2}}\right)-\left(\frac{1}{R_{3}}-\frac{1}{R_{4}}\right)\right\}
$$

Ten of the apparent resistivity value is:

$$
\rho_{a}=\frac{\Delta V}{I} 2 \pi\left(\frac{1}{R_{1}}-\frac{1}{R_{2}}-\frac{1}{R_{3}}+\frac{1}{R_{4}}\right)^{-1}
$$

If $k$ :

$k=2 \pi\left(\frac{1}{R_{1}}-\frac{1}{R_{2}}-\frac{1}{R_{3}}+\frac{1}{R_{4}}\right)^{-1}$

Then,

$\rho_{a}=\frac{\Delta V}{I} k$

With $k$ as the electrode geometric configuration.

The geometry factor for each electrode configuration has a different value. The most common configuration used in geoelectric measurements is:

1. Wenner configuration: the distance between $\mathrm{C}_{1} \mathrm{P}_{1}, \mathrm{P}_{1} \mathrm{P}_{2}$, and $\mathrm{P}_{2} \mathrm{C}_{2}$ is the same called $a$.

2. Schlumberger configuration: the distance of $\mathrm{C}_{1} \mathrm{O}=\mathrm{C}_{2} \mathrm{O}=s, \mathrm{P}_{1} \mathrm{O}=\mathrm{P}_{2} \mathrm{O}$ $=b$, with point $\mathrm{O}$ as the center of configuration with extrincivity value of $b / s=1 / 3$.

3. Dipole-Dipole configuration: the distance of $\mathrm{C}_{1} \mathrm{C}_{2}=\mathrm{P}_{1} \mathrm{P}_{2}=a, \mathrm{C}_{2} \mathrm{P}_{1}=n a$ with $n$ is the $\mathrm{n}$-th measurement.

Based on the equation [6], Geometric factors for Schlumberger configuration provided that $\mathrm{b}<<\mathrm{a}$ is :

$$
k_{\text {schlumberger }}=2 \pi\left(\frac{a^{2}}{b}-\frac{b}{4}\right)
$$




\section{METHOD}

This research was conducted at Nyelanding village, Air Gegas district, South Bangka. The site of the research was $2^{\circ} 44^{\prime}$ 54.514" South Latitude and $106^{\circ} 16^{\prime}$ 6.773" East Longitude.

\section{TOOLS AND MATERIALS}

The tools and materials used in this research were geoelectricity tools consisting of: superstring R8, Earth imager software, stainless steel electrode, walkytalky, geological hammer, and GPS.

\section{DATA COLLECTING TECHNIQUE}

The electricity data collecting technique was:

1. Determining the measurement track area.

2. Install the electrode on the track with spacing between electrodes of a maximum of six meters.
3. Connect all electrodes that have been attached to the switch box with a passive cable.

4. Connect the switch box to the Super Sting R8 / IP tool/console.

5. Check the electrode resistivity contact with the media through the main menu in the tool.

6. Make measurements.

7. Download data from the device to PC.

\section{DATA ANALYSIS TECHNIQUE}

The results of the geoelectricity measurements for the Schlumberger configuration using Multichannel Superstring R8 tools are Power current data (I), the Voltage (V), the spacing electrode (A, B, M, N) and type resistance $(\rho)$ in digital $*$ stg. Flow diagram of geoelectricity data processing can be seen in figure 4 .

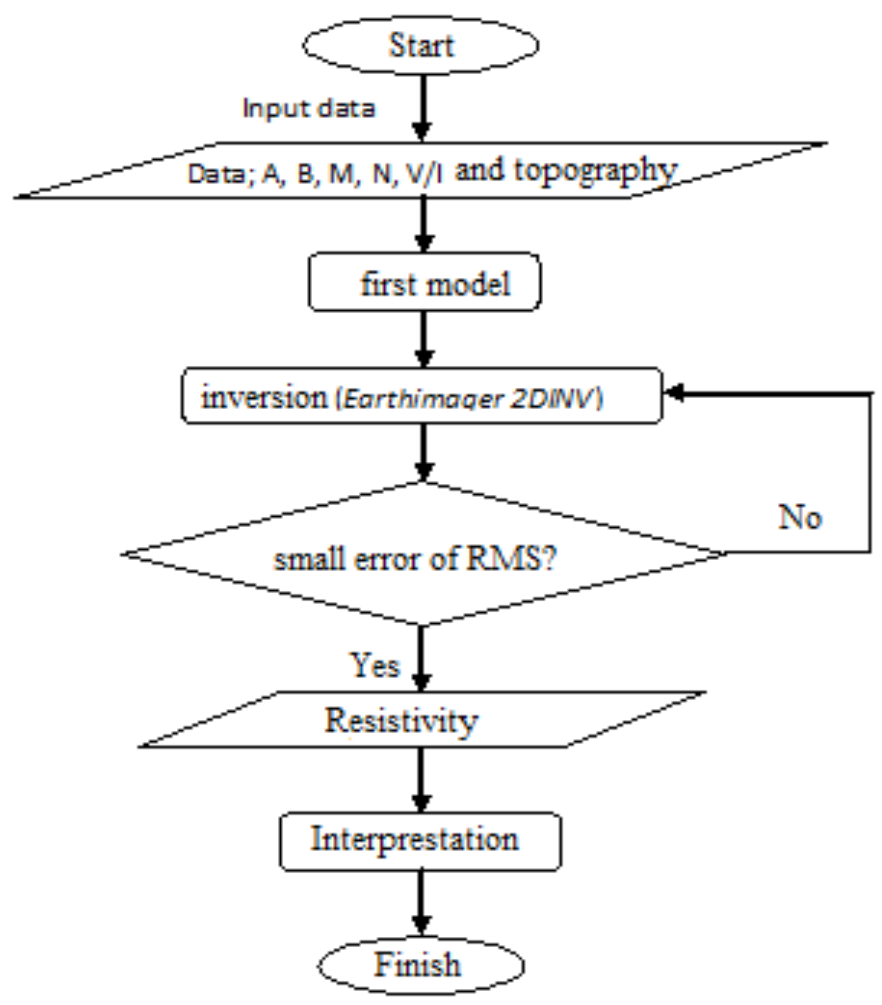

Figure 4. Data Processing Flow Chart

\section{RESULT AND DISCUSSION}

In this research, a measurement of Voltage $(V)$ and electric current $(I)$ in 3 different location at east $\left(106^{\circ} 16^{\prime} 21.2^{\prime \prime}\right)$, north (106 16' $21.2^{\prime \prime}$ BT - 2॰ 42'02.3" LS), and west $\left(106^{\circ} 16^{\prime} 19.5^{\prime \prime} \mathrm{BT}-2^{\circ}\right.$ 
41'59.1" LS) of the Nyelanding hot spring. The resistivity value of the 3 measurement points ranging from 45 to $1046 \Omega \mathrm{m}$.

The measurement diagram on track 1 (east of the hot springs) showed a resistivity value of $56.5-1046 \Omega \mathrm{m}$ as shown in Figure 5. The granite anomaly (1046 $\Omega \mathrm{m}$ ) was found at 2.5 meters deep with the distance of 9 meters from the starting point of measurement.
A decrease in resistivity around granite rocks showed a resistivity of 455$690 \Omega \mathrm{m}$ interpreted as sandstone. Sandstone is the result of weathering granite rocks. At a distance of 12 meters from the starting point of measurement (west of the site), the resistivity diagram showed the presence of groundwater at a resistivity of $56.6 \Omega \mathrm{m}$.

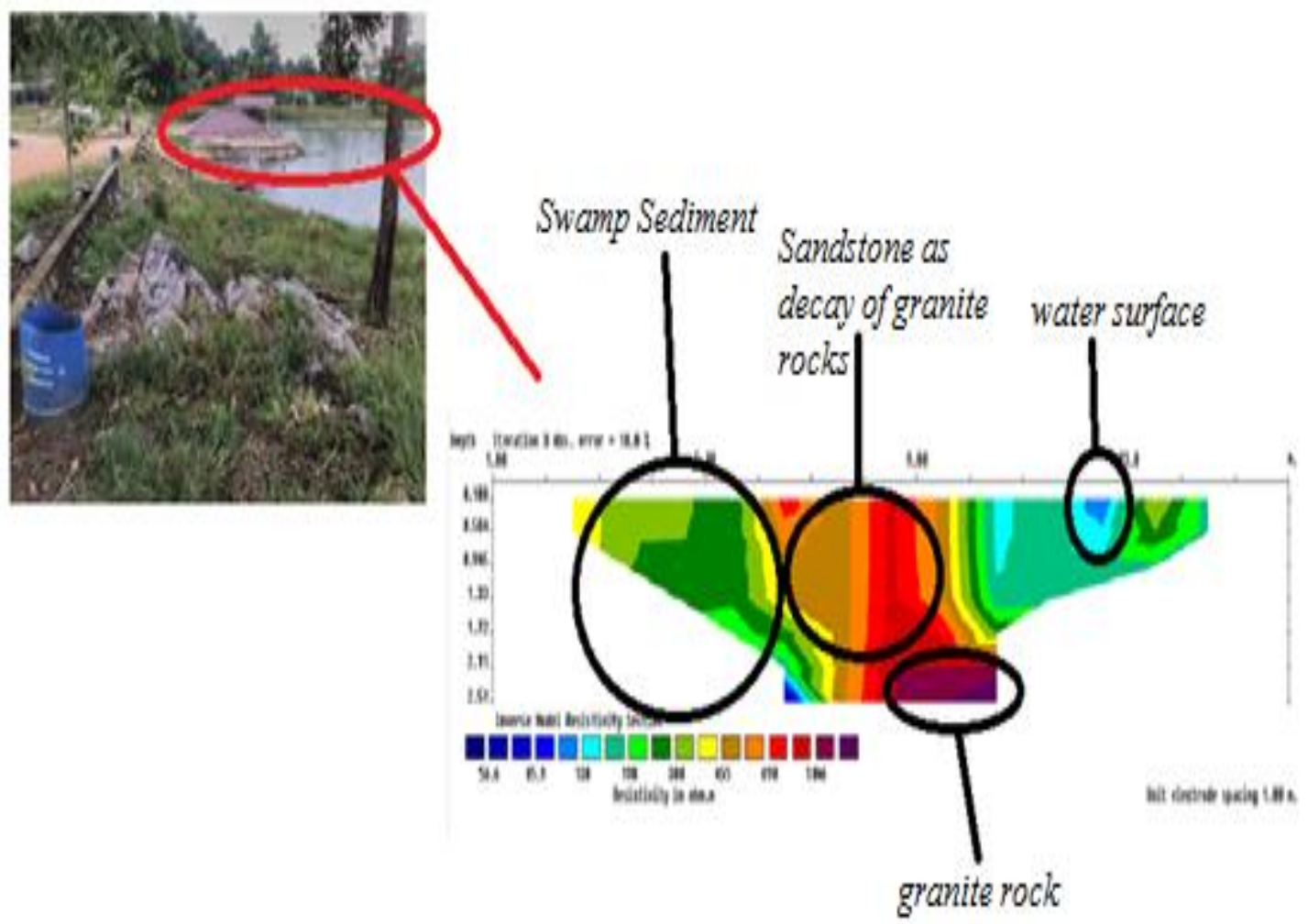

Figure 5. Resistivity diagram of track1

The track 2 located at the north of the hot spring showed a resistivity diagram ranging from 45 - $322 \Omega \mathrm{m}$. On this track, granite rock outcrops were found at the starting point of measurement. At a distance of 3 - 5 meters, resistivity showed the existence of granite rocks with a resistivity of $332 \Omega \mathrm{m}$ at a depth of 0.9 meters. At a distance of $8-16$ meters, the subsurface structure of the study area showed a low resistivity value, i.e., 45$59.6 \Omega \mathrm{m}$. This anomaly was thought to correlate with swamp and alluvium deposits (Figure 6). At a distance of 33 - 41 $\Omega \mathrm{m}$, the resistivity contours showed 185 to $138 \mathrm{~m}$ which were interpreted as sandstones, 


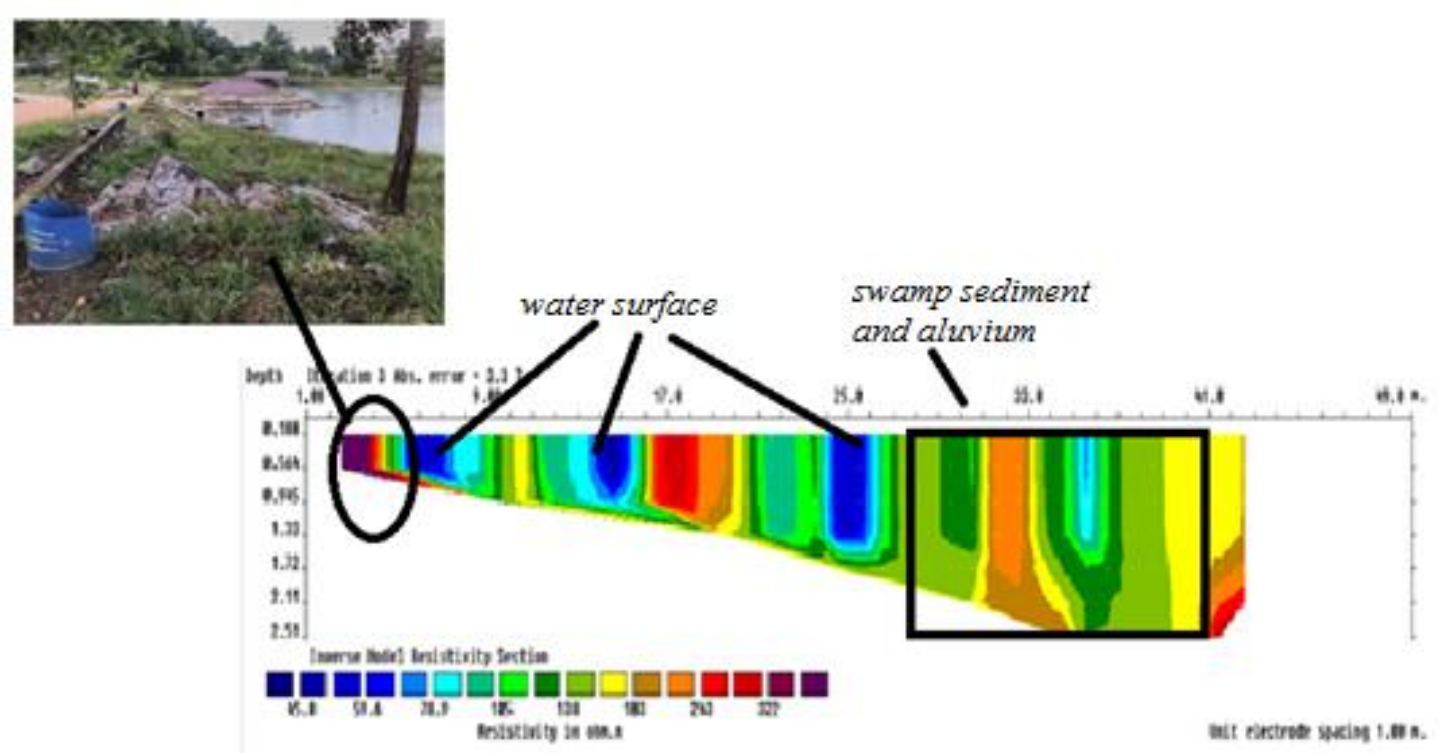

Figure 6. Resistivity diagram of track 2

The resistivity on track 3 showed a very clear granite axial contour as shown in Figure 7. The granite rock outcrop (Figure 5.3) was validated by a resistivity of $300-452 \Omega \mathrm{m}$ at a depth of 2.5 meters to 7-10 meters from the initial measurements point. An estimated fracture as a heat exitway from the carrier rock to interact directly with the surrounding layer was shown by the resistivity difference at a distance of 4-7 meters from 0.5-2.1-meter depth.

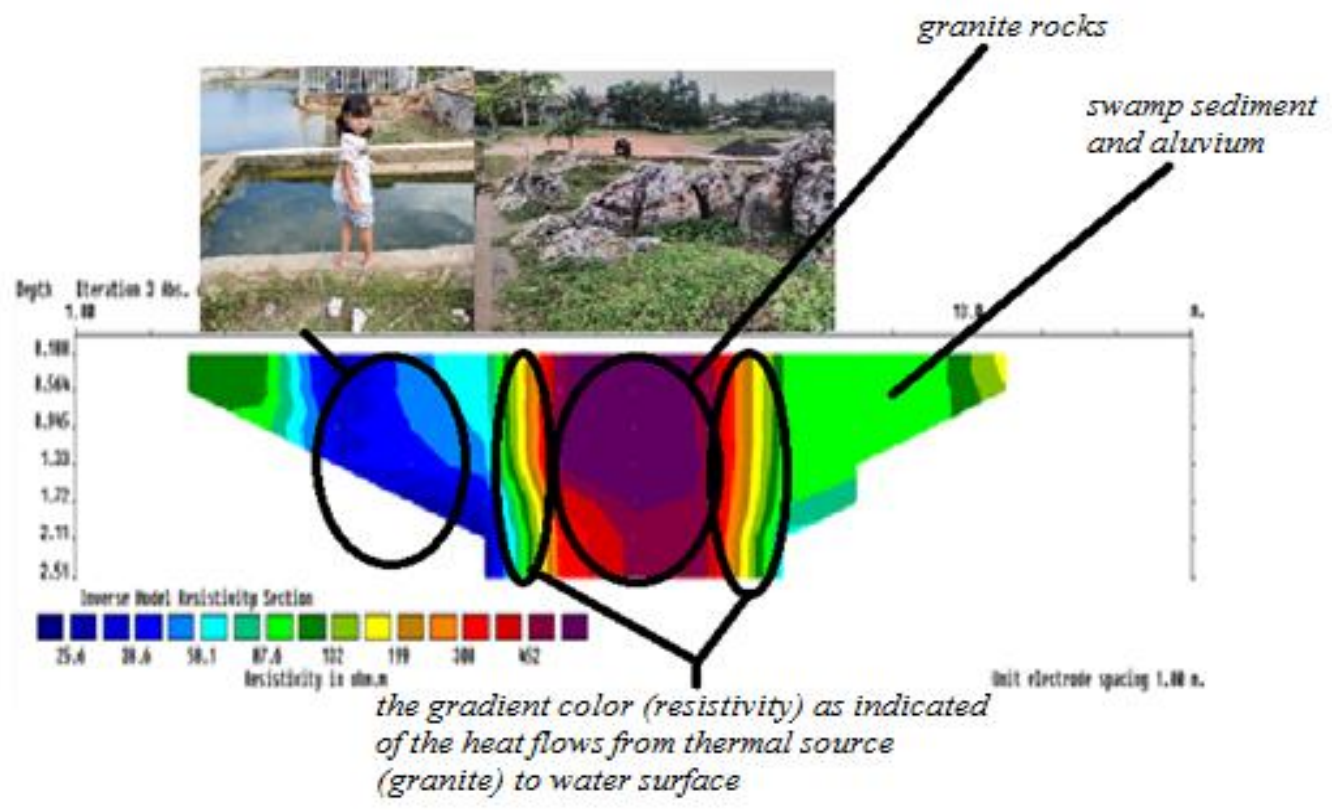

Figure 7. Resistivity diagram of track 3

\section{CONCLUSION}

Based on the research results, it was found in the resistivity diagram the existence of granite around Nyelanding hot spring with resistivity on track 1 (east of hot spring) showing resistivity value of 56 ,
5 - $1046 \mathrm{~m}$, on Track 2 which located at the north of the hot spring showed a resistivity diagram ranging from $45-322 \mathrm{~m}$ and a resistivity value approximately 300 - 452 m. Track 3 showed a very clear granite anomaly contours. High resistivity data 
indicated that the geological structure of the study area unrelated to the common hydrothermal alteration of rocks in the volcanic region.

\section{ACKNOWLEDGMENT}

The researcher's gratitude is dedicated to the University of Bangka Belitung which has provided support through University Lecturer Research Grant.

\section{REFERENCES}

Ananda, R. P., Ahman, E., \& Riwanudin, O. (2013). Pengaruh Physical Evidence Objek Wisata Pemandian Air Panas Ciwalini Terhadap Keputusan Berkunjung Wisatawan (Survei Pada Wisatawan Nusantara Pemandian Air Panas CiwaliniCiwidey Kabupaten Bandung). Tourism and Hospitality Essentials Journal, 3(1), 461-482.

Barber, A. ., Crow, M. ., \& De Smet, M. E. (2005). Sumatra: Geology, Resources and Tectonic Evolution. Geological Society Memoir, 234257.

Franto. (2015). Interpretasi Struktur Geologi Regional Pulau Bangka Berdasarkan Citra Shuttle Radar Topography Mission (SRTM). Jurnal Promine, 3(1), 10-20.

Margono, U., Supandjono, R., \& E, P. (1995). Peta Geologi Lembar Bangka Selatan, Sumatera. Bandung: Pusat Penelitian dan Pengembangan Geologi.

Muslim, D., Kristiyanto, T. H., \& Endyana, C. (2015). Peran Patahan Aktif Dalam Pengelolaan Sumber Daya Geologi, Studi Kasus : Sumber Daya Lahan Di Wilayah Jatinangor. Proceeding Seminar Nasional Ke-2 FTG Universitas Padjadjaran, 5662. Retrieved from http://seminar.ftgeologi.unpad.ac.id/ wp-content/uploads/2016/03/Peran-
Patahan-Aktif-Dalam-Pengelolaan-

Sumber-Daya-Geologi.pdf.

Permana, H., Handayani, L., \& Gaffar, E. Z. (2010). Studi Awal Pola Struktur Busur Muka Aceh, Sumatera Bagian Utara (Indonesia): Penafsiran dan Analisis Peta Batimetri. Jurnal Geologi Kelautan, 8(3), 105-118.

Pitulima, J., Siregar, R. N., Pertambangan, J. T., Belitung, U. B., Fisika, J., \& Belitung, U. B. (2016). Identifikasi Struktur Geologi Sumber Air Panas Non Volkanik Desa Nyelanding Bangka Selatan. Prosiding Seminar Nasional Riset Terapan, 5662, 63-70. Purwoto, E., Rezky, Y., \& Simarmata, R, S, L. (2015). Survey Aliran Panas (Heat Flow) Daerah Panas Bumi Permis Kabupaten Bangka Selatan, Provinsi Bangka Belitung. Bandung.

Santoso, A. B. (2016). Air Panas Berbelerang di Tirta Tapta Pemali Bangka Ini Bisa Sembuhkan Aneka Penyakit Kulit. Tribunnews.com. Retrieved from http://www.tribunnews.com/travel/2 016/02/01/air-panas-berbelerang-ditirta-tapta-pemali-bangka-ini-bisasembuhkan-aneka-penyakit-kulit.

Setiawan, D, L., \& Adhitya, L. (2013). Geologi dan Geokimia Panas Bumi Daerah Permis Kabupaten Bangka Selatan, Provinsi Bangka Selatan, Kelompok Penyelidikan Panas Bumi. Bandung.

Siregar, R, N., Sinarta, I, N., Ervan, M., \& Sismanto. (2016). Ground Penetrating Radar and 2-D Electricity Application for Detecting Landslide in Abang District, Karangasem Regency, Bali. International Journal of Engineering Research and Application, 6(7). 